\title{
ロGISによる総合防災マップと地すべりハザードマップ 一四国と中米ホンジュラスの例—
}

\author{
Integrated Disaster Prevention Maps and Landslide Hazard Maps using GIS \\ -Examples of Shikoku and Central America Honduras-
}

山岸宏光* Hiromitsu YAMAGISHI／愛媛大学 Ehime University

キーワード：総合防災マップ, 四国, 地すべりハザードマップ, ホンジュラス

Key words : Integrated disaster prevention map, Shikoku, Landslide hazard map, Honduras

\section{まえがき}

最近，災害ハザードマップなど災害関連マップはGIS 技術によって作られるようになってきた。とくに，2011 年 3 月 11 日の東日本巨大災害は全国的に，いわば多重災 害ハザードマップの作成を促進させてきた。なぜなら， とくに四国から東海地方にかけての太平洋沿岸地域では, 来たるべき南海トラフ巨大地震が，津波（図－1）だけ でなく，地すべり，崩壊，土石流などの土砂災害を同時 に発生させる危惧があるからである。したがって，本報 告では四国地方を例に, 沿岸地域の多重災害危険度マッ プの作成例について紹介する。さらに内陸の災害の典型 である，地すべり災害のハザードマップ作成の中間的報 告を, 中米ホンジュラス国テグシガルパ市の例をあげて 紹介する。

\section{1. 四国地方の災害因子}

四国地方は我が国のなかで最も山地が最も多く $80 \%$ を 占めており, 地すべり地形も 3 万か所を数えて, 我が国 全体の $10 \%$ を占めている（防災科研地すべり地形分布図

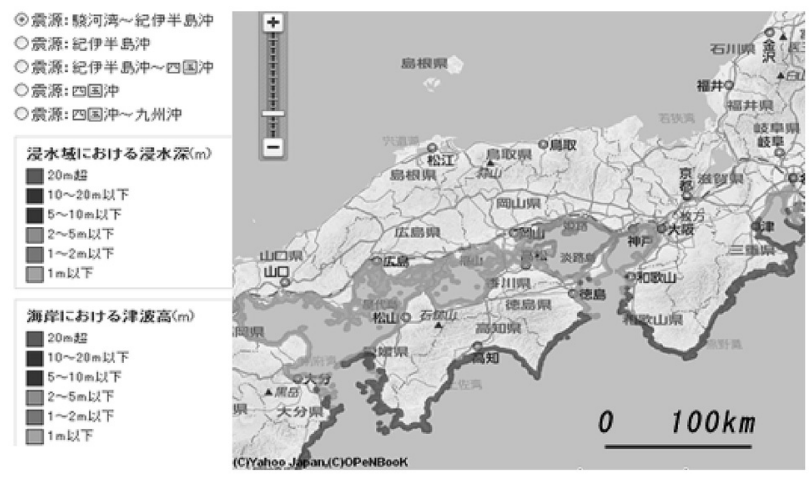

図一 1 内閣府による南海トラフ巨大地震による津波の想定 (Yahoo Mapによる)

Fig. 1 Tsunami inudation map due to Nankai Trough Big Eearthquake by Cabinet Office, Japan. This map is from Yahoo Japan map

連絡著者/corresponding author

テ003-0025 札幌市白石区本郷通り 2 丁目北 3 の 10 の207

Kita 3-10-207, Hongodori 2, Shiroishi-ku, Sapporo 003-0025, Japan e-mail : hiromitsuyamagishi88@gmail.com
データベースURL http://lsweb1.ess.bosai.go.jp/)。ま た，四国南西部は典型的なリアス式海岸であり，来たる べき南海トラフ巨大地震では，最大津波浸水予想高は34 $\mathrm{m}$ を超える海岸もあると想定されている。2011年 3 月 11 日の東日本大震災では，津波被害の甚大さにくらべて土 砂災害は少なかった。このことは，陸からやや遠い海溝 型地震であったことや，背後の地質地盤が中古生代の古 く硬い岩盤であったことが指摘され，地すべり地形はほ とんど分布していない地域である。

しかし, 四国では, 徳島県から愛媛県にかけての地域 は三波川带とよばれる変成岩地带で, 我が国でも有数の 地すべり地帯（図－2）である。したがって，南海トラ フ巨大地震が発生した場合, 四国南西部の海岸では, 東 日本大震災と同様な津波被害が予想されると共に, 2004 年10月23日の中越地震のように地すべり災害が多発する ことも予測される。また，四国地方の特殊性として，香 川県，愛媛県を中心に 3 万箇所に達するとされる溜池の 決壊や土砂流失によるオーバーフローなども危惧される。 こうしたことから, 愛媛大学防災情報研究センターでは,

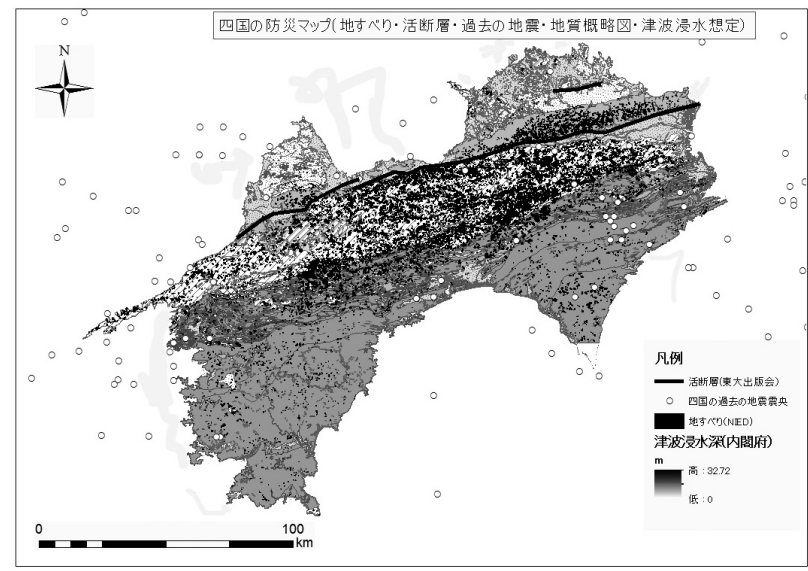

図－２四国の地質図（地質総合センター，，活断層（東大 出版会を一部簡略化), 過去の地震分布, 津波想定 （内閣府）地すべりを含む総合防災マップ

Fig. 2 Integrated disaster map of Shikoku including geologic map, active faults, past epicenters, tsunami, deep-seated lanslides 
2010年から南海・東南海地震研究部門と防災GIS研究会 を立ち上げ，さまざまGIS防災情報の作成や，可視化技 術の検討を行ってきた。愛媛県では，東日本大震災以前 から防災データが準備され，陸上の震度分布，地表加速 度分布，安政地震（1854年）をもとに作られた津波到達 時間，津波高などのデー夕も存在していた（図-3）が 多くは未公表であった。その後, 2013年 6 月には初めて 土砂災害や津波浸水予想区域についての簡略なデー夕が 愛媛県から公開された（図一 4 ; 愛媛県ウェブサイト http : // www.pref.ehime.jp/bosai / higaisoutei / higaisoutei24.html）。（参照日2013年 7 月17日）

また，四国地方では，1854年の安政地震のように，南 海トラフに起因する海溝型地震のほかに，瀬戸内海や宇 和海などの地震をはじめ，我が国では第一級の活断層で ある中央構造線が走っている(図-2)。これらの内陸 型の地震も無視できず，その評価も重要である。

さらに，全国的なことではあるが，地震のみならず豪 雨をトリガーとした崩壊も時折発生していて, 最近でも,

\section{松山市周辺の地震被害予測図（旧情報） (4次メッシュ $500 \mathrm{~m} \times 500 \mathrm{~m}$ )}

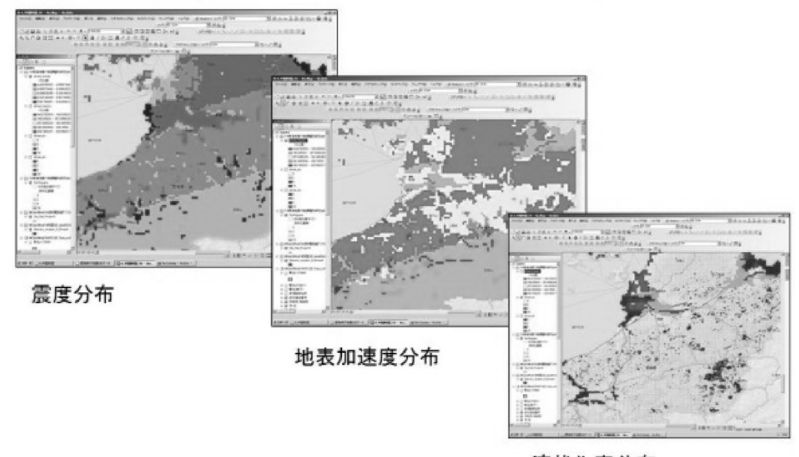

液状化率分布

図ー 3 安政地震をモデルとした地震被害予想図 (愛媛県)

Fig. 3 Maps showing seismic intensity, acceralation and liquefaction distribution of Matsuyama area (Ehime Pref.)

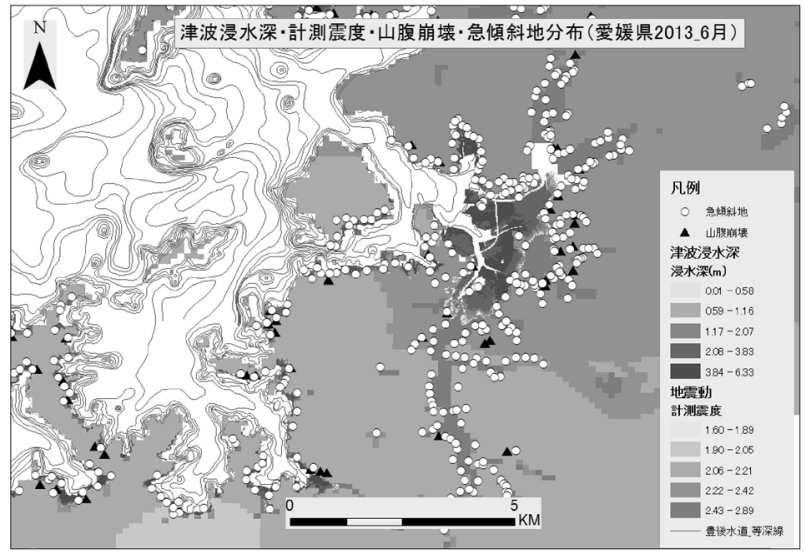

図一 4 南海トラフ巨大地震による浸水域想定（愛媛県宇和 島付近）をGISで表示した。

Fig. 4 Map showing tsunami inudation area by Nankai Trough Earthquake (Uwajima, Ehime Prefecture)
2004年 9 月の新居浜を襲った豪雨による表層崩壊（Yamagishi et al. 2013）や，2010年 9 月の高知県奈半利川上 流の平鍋ダム付近の深層崩壊がある（笹原ほか，2012）。

\section{2. 愛媛大学防災情報研究センターでのGIS}

愛媛県では, 2011年 3 月11日の東日本大震災の前か ら,1854年の安政地震をモデルとした津波到達海岸での 波高や内陸の震度, 地表加速度, 液状化率など, いづれ も500mメッシュの粗いデータではあるが，すでに作成 されていた。また，地すべりや崩落危険度マップ，土石 流危険度域マップなども同様であった。しかし，津波到 達波高デー夕などはGISで作られたものでなかったため, 愛媛大学では，作業機関と協議しつつGIS化してきた(図 $-3 ， 4$ および 5 )。巨大地震の発生は海岸のみならず, 低地での液状化災害，丘陵や山地での土砂災害などが同 時に発生する。したがって，避難所や避難道路の安全性 についても，津波だけでなく土砂災害への対応など総合 的に評価する必要がある。また，これらのデー夕を誰で も見えるようにするには，一般的なプラットフォームが 必要である。今回はGoogle earthで表示することにした。 このプラットフォームを使うと，ネット環境でさえあれ ば，三次元表示もできるし，自分でデジカメ写真の追加 もできる。

東日本大震災が発生した三陸海岸と違い，四国の南西 部海岸は三波川带という地質帯に地すべりが集中する地 域に相当している。つまり，破砕帯と呼ばれる割れ目の 多いクシャクシャの岩盤が特徵であり (図- 2 ), 上記 のように南海トラフ巨大地震の発生の際には，津波のみ ならず崩壊や土石流災害などが同時多発的に発生するこ とは確実であり（図－6），こうした総合防災マップと いったものが必要になる。2004年10月24日の中越地震な ど最近の中山間地を襲った地震では，既存地すべり地で の土砂災害発生危険度は他と比べて異常に高かったとい う研究がある（野呂ほか，2011）。特に中越地震での地 すべり発生は，既存地すべり地内が50\%に達したと報告

\section{第一波津波到達時間(分)、最大津波 到達時間(分)、最大波高 $(\mathrm{cm})$}

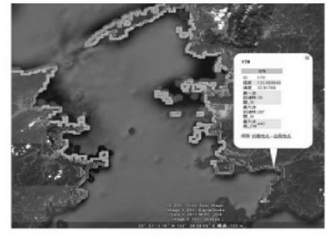

宇和島には、第一波は1時間後、

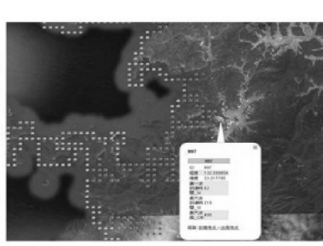

図ー 5 安政地震 (1854) をモデルとした津波シミュレーショ ンによる到達時間, 最大波到達時間, 最大波(愛媛県)

Fig. 5 Maps showing the Tsunami reaching time and the maximum height along the coast of Ehime Prefecture. based on 1854 Earthquake 
されている。

また，四国特有の溜池（筆者の調査では，少なくとも 1 万 5 千箇所を数える）の存在も，災害の要因となりう る要素である。つまり, 近年の都市化によって溜池近く への住宅地の進出で，溜池の決壊や土砂流入による越流 などによる災害も危惧されている。たとえば, 愛媛県東温 市の丘陵部にも多数の溜池が存在しているが，それと災 害危険要因を重ねてみると, 多数の溜池が地すべりや土 石流の影響を受けやすいものがあることがわかる(図-7)。

\section{GISを活用した地すべりハザードマップの試みーテ グシガルパ市の例一}

筆者は，2011年から2014年までの期間，JICA Expert として，中米ホンジュラス国のテグシガルパにおいて， ホンジュラス工科大学 (UPI) や自治大学 (UNAH) を 中心に，地すべり災害ハザードマップ作成指導を行って いる。このプロジェクトには山形大学の八木浩司教授, 帝京平成大学の佐藤剛准教授がともに参加している。本

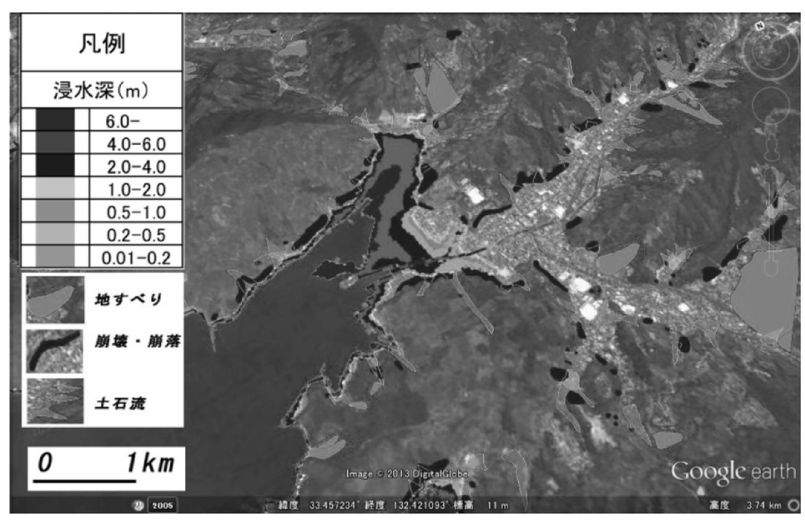

図一 6 津波浸水想定域，地すべり・崩落・土石流危険域を 含む総合防災マップ（Google Earth）の一例（愛媛 県八幡浜付近)

Fig. 6 An example of integrated hazard maps including not only tsunami inudation, but also danger zones of landslides and debriflows (Yahatahama, Ehime Pref.)

溜池と土砂災害危険地区との関連(愛媛県東温市)

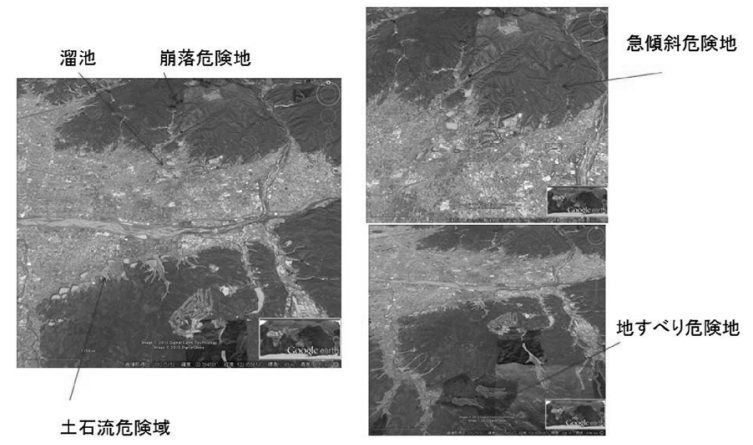

図ー7 ため池と土砂災害発生予測分布との関連を示す (Google Earth)

Fig. 7 Maps showing the relationship between ponds and landslides and debris flows around Toon City, Ehime Pref. (Google Earth)
文は，彼らとの共同で，写真判読をもとにGISで地すべ り地形と道路や河川との関連, 地質や地形, 種々のイン フラとの関連づけを行い，AHPによるハザードマップ 作成指導を実施している。本報告はその中間過程の紹介 である。

\section{1 地すべりハザードマップとは}

“Landslide hazard map”という言葉は，あいまいな 言葉であり，さまざまな意味をもっていると思われる。

最近では，各自治体で防災マップと同意語で“ハザー ドマップ”という言葉がよく使われている。しかし，そ れぞれの災害ターゲットにより，その意味するところは 異なるであろう。

“地すべりハザードマップ”とか“土砂災害ハザード マップ”と呼ばれるものも色々あると思われる。“GIS Landslide”の分野においても同様である。筆者の経験 では, GISでlandslideを扱う国際雑誌の論文の審査の際 に悩まされるのは，その論文で扱う“landslide”は一体 何を意味するのかわからないことである。和文で論文を 書くときは, 崩落 (fall), 崩壊 (failure), 地すべり (deep -seated landslide) という言葉が使われることが多く, 合理的である。また，一般的に使われる“ハザードマッ プ”の中で，“土砂災害ハザードマップ”は，崩落危険 度マップ (急傾斜危険マップ), 地すべりハザードマッ プ（地すべり危険度帯のゾーニング）などを総合的に扱っ たものであろう。本報告で扱う “landslide hazard map” は，日本語でいう“地すべりハザードマップ”でスペイ ン語では，“deslizamientos mapa de riesgos”に相当す る。また，一般的に使われているLandslide Hazardの定 義もあいまいであり，国際雑誌に載るようなGIS Landslide Hazard Mapはどれだけ実用化されているであろう か。つまり, GIS解析では, 地質, 地形, 土地利用, 降 雨量などさまざまなfactorの “重み付け”を行って点数 を与えて計算させた結果が “GIS Landslide Hazard Map”とされている。しかし，その後に，危険度の高 いゾーンには実際にlandslideが多く発生したかどうか実 証されたものがあるだろうか。つまり，実用的でないも のが多い。

\section{2 地すべりハザードマップの種類}

アメリカの科学アカデミーのCommittee on the Review of the National Landslide Hazards Mitigation Strategy (CRNLHMS, 2004) は “Landslide hazard map”を以下のように 4 区分している。

1) landslide inventory map, 2 ) Iandslide susceptibility map, 3 ) landslide hazard map, 4) landslide risk map。

GISで作成されるLandslide hazard mapの多くは 2) のIandslide susceptibility mapに相当するように思われ る。また，写真判読で作成されるのが 1 ）のInventory map（図-8）であり，次の段階で 2）のsusceptibility map ということになり，人間的要素（被害）が入って 


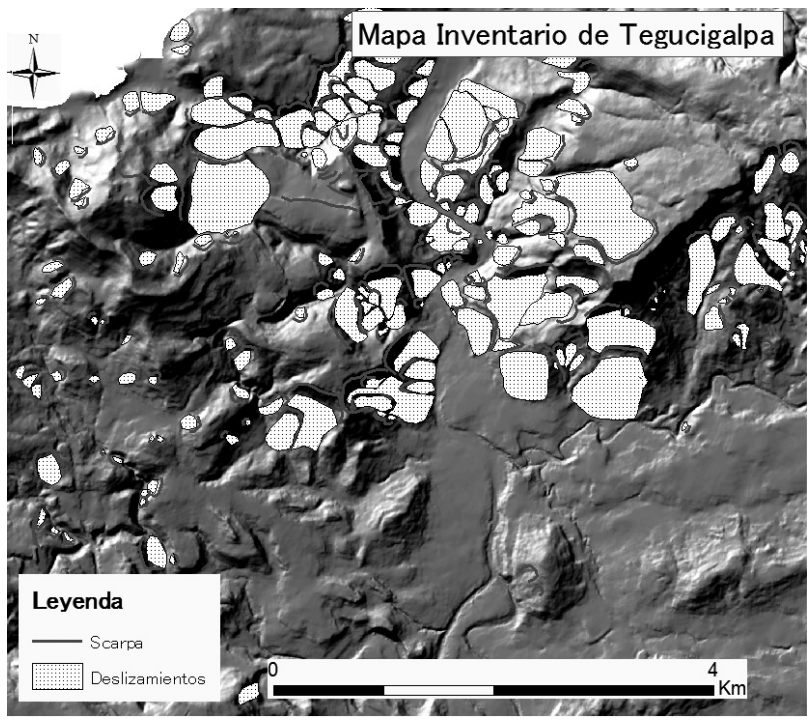

図ー8＼cjkstart空中写真判読によるテグシガルパ市周辺の地すべり 地形分布 (八木, 佐藤による)

Fig. 8 Landslide Inventory map of Tegcigalpa based on airphotograph interpretation by Yagi and Ssato

初めて，3）教義のlandslide hazard mapということに なると解釈される。

なお，参考までにCRNLHMS（2004）の定義を原文 のまま掲載すると，以下のようである。

1) A landslide inventory map shows the locations and outlines of landslides. A landslide inventory is a data set that may represent a single event or multiple events. Small-scale maps may show only landslide locations, whereas large-scale maps may distinguish landslide sources from deposits, classify different kinds of landslides.

2 ) A landslide susceptibility map ranks slope stability of an area into categories that range from stable to unstable. Susceptibility maps show where landslides may form.

3 ) A landslide hazard map indicates the annual probability (likelihood) of landslides occurring throughout an area. An ideal landslide hazard map shows not only the chances that a landslide may form at a particular place, but also the chances that a landslide from farther upslope may strike that place.

4) A landslide risk map shows the expected annual cost of landslide damage throughout an area. Risk maps combine the probability information from a landslide hazard map with an analysis of all possible consequences (property damage, casualties, and loss of service).

今回，八木浩司・佐藤剛両氏による白黒空中写真判読 で作成されたTegucigalpa市のlandslide inventory map (図－8）をGISでポリゴン化し，ASTER_GDMによる $30 \mathrm{mDEM}$ 地形データを使って地すべりの発生地点（滑
落崖ラインの中心点)の標高を調べると, 標高1100-1200 $\mathrm{m}$ の地点が最も多いことが分かった（図－9 aおよび $9 \mathrm{~b}$ )。 さらに，地すべり地形（移動体）と地質との関連を見る と, 地すべり地形の数でみても，面積率でみても，溶結 凝灰岩の部分に多いことがわかる（図－10aおよび10b）。 つまり，Tegucigalpa北部の地すべり集中域は，上面が 平坦な溶結凝灰岩がキャップロック構造をなしている。

また，テグシガルパのハザードマップ作成の過程では, まず，川までの距離が $250 \mathrm{~m}$ 以内（日本の土砂災害防止 法施行令 第二条には，土砂災害警戒区域の範囲として， 地滑りが動いた場合，その先端から最大が $250 \mathrm{~m} ）$ の地 すべりを検索した（図-11a）。一方，同じく250m以内 の道路と地すべりの分布も属性選択で調べた（図-11b）。 とくに, Tegcigalpa市の真ん中を北へ流れるCholtega Riverは，北部の狭窄部を横切るが，その川の両側は活 動的な地すべりが多数存在していて，それらが再活動す ると，その河川が閉塞してしまい，Tegcigalpa市の中心 部が水没する危険が高まる恐れがある。また，ほかの方

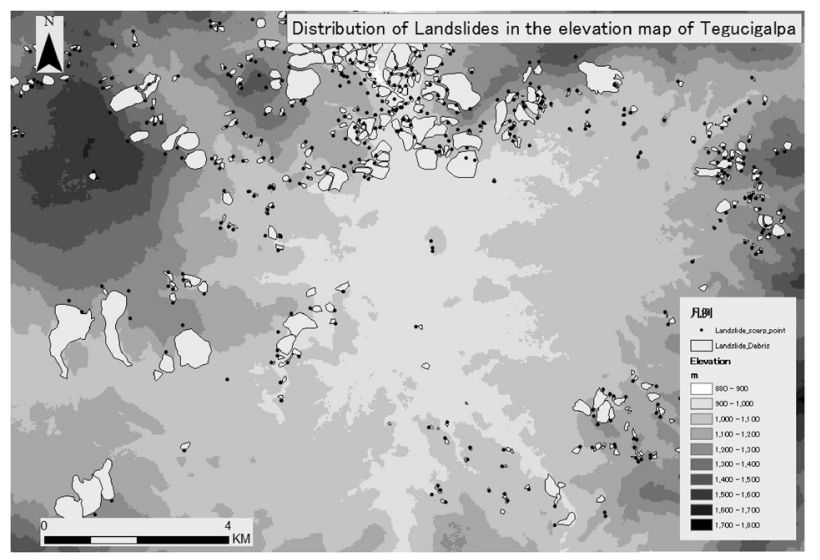

図一 9 a 地すべり発生点と標高との関係

Fig. 9a Map showing the relationship between landslide and elevation

LANDSLIDE DITRIBUTION AND ELEVATAION OF TEGUCIGALPA

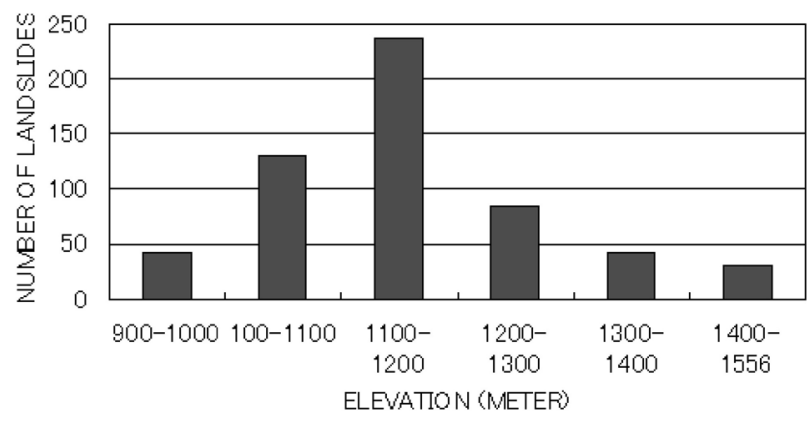

図ー9bテグシガルパ市周辺の地すべり数と標高との関係 (1100-1200mに集中している)

Fig. 9b Bar graph showing the elevation of generating of the landslides in Tegcigalpa. Notice that 1100 to $1200 \mathrm{~m}$ zones have highest zone of landslide genaration 


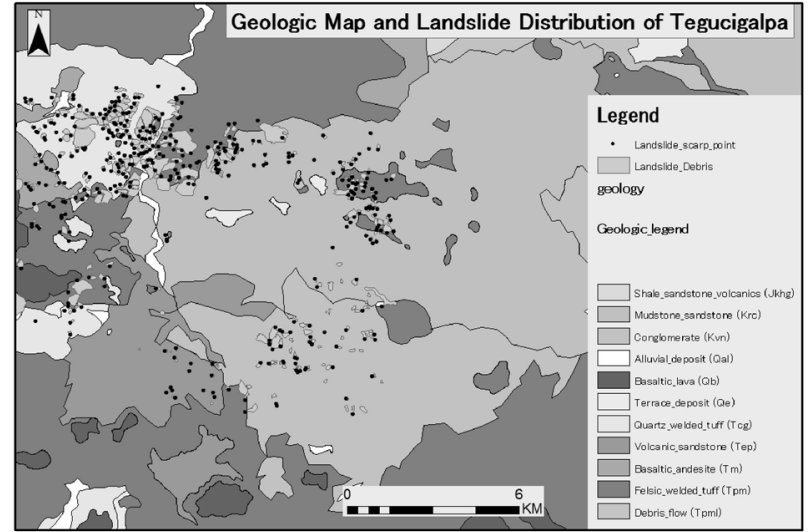

図ー10a＼cjkstart地すべり分布と地質岩相との関係

Fig. 10a Lanslide distribution and gelogic map

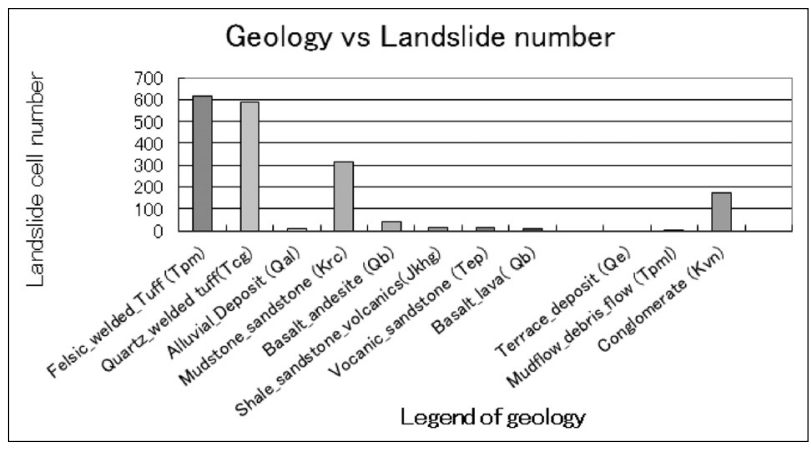

図ー10b＼cjkstart地すべり数と地質岩相との関係を示すグラフ（溶 結凝灰岩に多いことがわかる)

Fig. 10b Bar graph showing that the most of the landslides generated from the welded tuffs which make up the cap rock structure

法で作成されたハザードマップとの組合わせでも，地す ベり地形内だけでなく，判読されない部分も評価できる。 その意味で，今回，ホンジュラスのUNDP（国連開発計 画）から提供されたテグシガルパ市の地すべりハザード マップも有用である。

つまり，Tegcigalpa市のUNDP（国連開発計画）でも， “地すべりハザードマップ”（AMENZA MAPA）を作成 していて，最近のバージョンアップしたものをみると， 判読地すべり地形の集中域 (北西部) は危険度最大のAlta zoneに一致する (DEMによる傾斜度の高い地域らしい： 図-12)。しかし，この急傾斜带の多くは，地すべり地 形の滑落崖にあたる。最近の災害はむしろ地すべり地内 緩傾斜に多く発生している。

以上の結果は，途中経過であり中間的なものである。 今後は, これらの写真判読も最近撮影されたカラー写真 を使って，再度判読を行い，それにもとづいてinventory mapを作成し，それぞれの地すべり地の活動度や別のプ ロジェクトで実施されているボーリング孔の計測デー夕 を属性デー夕に追加する。同時に, 5 人程度の地すべり判 読者により，地形的特徵を含めた種々の要素から AHP 法で危険度判定を（Miyagi et al., 2004など）行うこと になる。その場合は，2003年に地すべり学会が新潟県阿

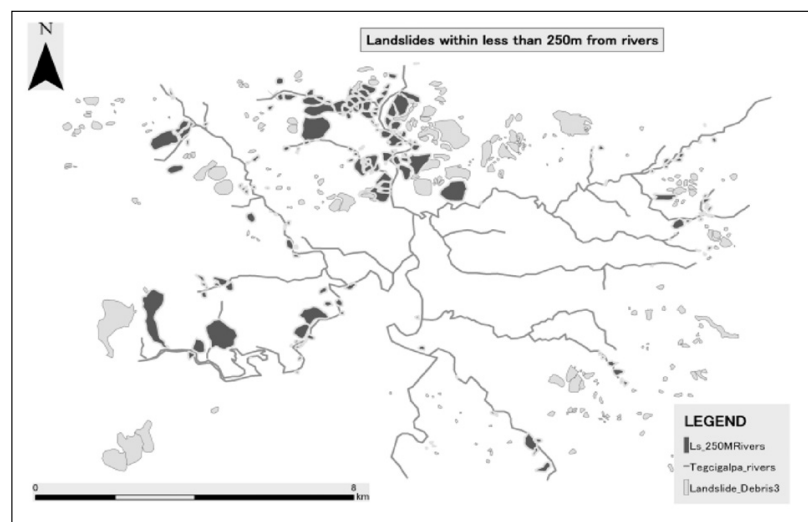

図ー11a＼cjkstart河川から250m以内にある地すべりを示す（GISで 計算)

Fig. 11a The landslides within $250 \mathrm{~m}$ from the rivers, found by attribute selecion of GIS

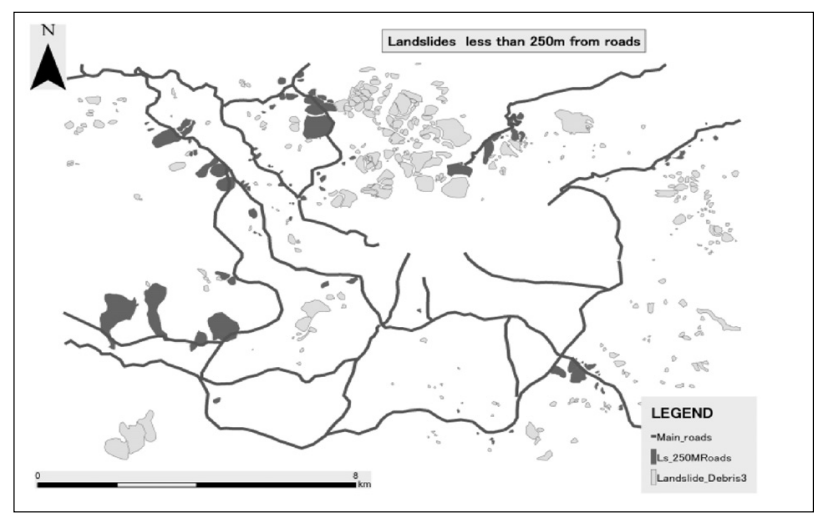

図一11b 主要道路から $250 \mathrm{~m}$ 以内にある地すべり分布

Fig. 11b The landslides within $250 \mathrm{~m}$ from the main roads, found by attribute selection of GIS

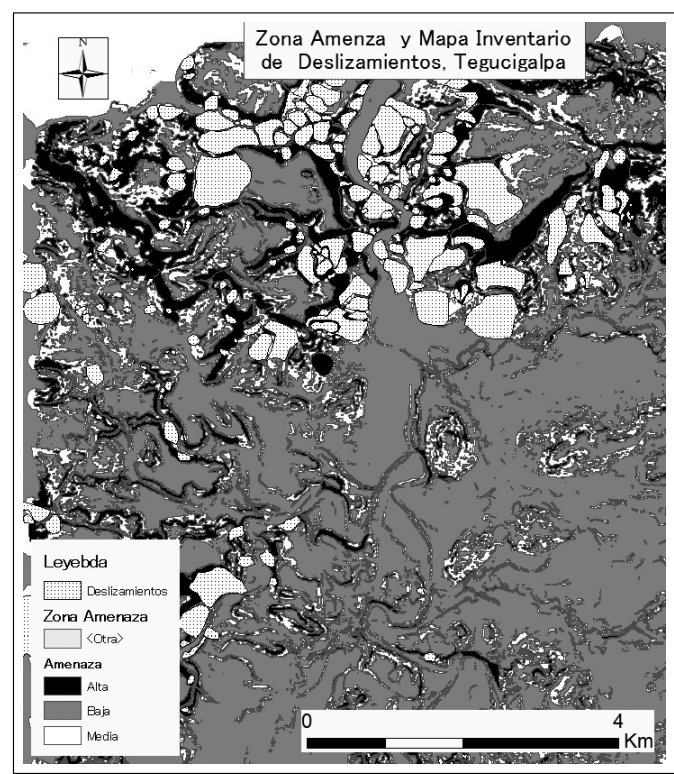

図一12 国連開発計画（UNDP）による地すべり危険度マッ プ (斜面区分) と八木・佐藤による地すべりマップ をオーバーレイしたマップ

Fig. 12 Landslide Hazard Map (UNDP_Map overlain by Inventoried lanslides by Yagi and Sato) 
賀野川で国土交通省の委託をうけて実施した例（八木ほ か，2009；図－13）が参考になる。

\section{4. まとめ}

今回は総合防災学ともいえる資料について，愛媛県を 中心に作成した報告と, 中米ホンジュラスの首都テグシ ガルパ市の地すべり危険度マップの作成の一端を紹介し た。いずれも，最近の新しい技術ともいえるGISを活用 した。とくに，ホンジュラスのテグシガルパの地すべり については，1998年ハリケーンミッチの大災害以来， Harp et al.（2002）がGISを活用したLandslideの研究の 報告で，各地質相に土質係数を与えてラフなハザード マップを試みている。その後も最近ではVanWesten et al. (2008) が，テグシガルパのデジタルデータを紹介 した論文も発表している。

しかし，これらのデータや成果が現地ホンジュラスの 技術者などに生かされた形跡がない。それは，現地に受 け皿となるべき機関や人材がいないためであり，演者ら が実施しているJSPS-JICAの専門家派遣事業の実施する 理由ともなっている。つまり，これらの論文が実用的に 生かされるには，現地の研究者や技術者による計測や現 地踏査などのデータとを組み合わせる必要がある。その 意味でも，2013年 3 月16-22日に開催された第 1 回中米 一カリブ海地すべり会議は，この地域での地すべり対策 や教育にとってのネットワークづくりへの，大きな第一 歩であった。今後の活動に期待したい。

以下のサイトに本会議の講演要旨とプレゼンすべてが 公開されている (http：//congresosdedeslizamiento. $\mathrm{com} /$ )。（参照日2013年 5 月10日）

\section{あとがき}

本報告は2013年 5 月 24 日に開催された日本地すべり学 会シンポジューム「地すべり災害の対応一技術の変遷と 課題一」で発表したものである。二つの異なったテーマ で，第 1 は来るべき南海トラフ巨大地震のために用意す べき巨大地震にともなう多様な災害を扱う「総合防災 マップ」のGIS可視化について紹介したものであり，第 2 は中米ホンジュラスで実施中の“地すべりハザード マップ”の作成例を示したものであるが, on goingのテー マである。これをより実用的にするには，まずは，写真 判読に始まってGIS化と扱いの習得した技術者の教育が 必要で，そのうえでマッピング・GIS解析と現地デー夕 の収集・解析とをお互いにフィードバックしながら進め ていく必要がある。

\section{謝 辞}

第 1 のテーマについては，デー夕を提供いただいた愛 媛県危機対策課，デー夕作成に協力いただいた愛媛大学 GIS研究会和田壮平氏に謝意を表する。また第 2 のテー マについては, JICAホンジュラス事務所の方々, 写真

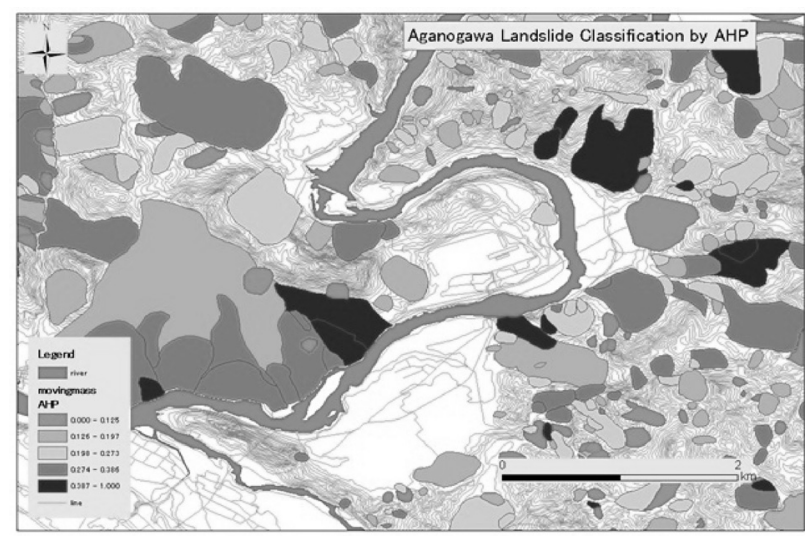

図一13 新潟県阿賀野川流域の地すべり危険度評価マップ (八木ほか, 2009)

Fig. 13 Map showing a landslide susceptibility classification along the Agano-gawa, Niigata Prefecture (Yagi et al., 2009)

判読をしていただいたJICA-JSPSの科学技術派遣専門家 として協力いただいた八木浩司・佐藤剛両博士に感謝する。

\section{参考文献}

1) Committee on the Review of the National Landslide Hazards Mitigation Strategy (CRNLHMS, 2004) : Partnership for reducing landslide risk. The National Academic Press, Washington DC, 123p.

2 ）笹原克夫 - 桜井亘 - 加藤仁志 - 島田徹 - 小野尚哉 (2012)：LiDarによる深層崩壊発生斜面の地形学的検討一平成 23 年台風 により高知県東部に群発した深層崩壊の事例解析一, 京都大 学防災研究所 特定研究集会, $23 \mathrm{C}-03$, 哚層崩壊の実態, 予測，対応 (研究代表者 千木良雅弘), p. 1-10.

3 ) Harp, E. D., Held, M. D. and Mckenna, J. P. (2002) : Digital inventory of landslides and related deposits in Honduras Triggered by Hurricane Mitch, USGS. Open file Report p. 2-61.

4 ) Miyagi, T., Prasad, G. B., Tanavud, C. , Potichan, A.and Hamasaki, E. (2004) : Landslide risk evaluation and mapping Manual of aerial photo interpretation-, Report of the National Research Institute for Earth Science and Disaster Prevention, No. 66, p. $75-137$.

5 ）野呂智之・松山清輝・ハスバートル・中村明（2011）：既存地 すべり地形に扔ける地震時地すべり発生危険度評価手法に関 する研究，土木研究所資料，第 $4202 ， 60 \mathrm{p}$.

6 ) Van Westen, C. J., Castellano, E. and Kuriakose, S. L. (2008) : Spatial data for landslide susceptibility, hazard, and vulnerability assesmen: An overview. Engineering Geology, Vol. 102 , p. $112-131$.

7 ) 八木浩司・桧坦大助 (2009)：(社) 日本地すべり学会平成14年 度第三系分布域の地すべり危険箇所調查手法に関する検討委 員会（2009）：空中写真判読とAHP法を用いた地すべり地形 再活動, 危険度評価手法の開発と阿賀野川中流域への適用, 日本地すべり学会誌, Vol. 45, p. 358-366.

8 ) 山岸宏光 (2012) : 南海トラフ巨大地震のためのGISデータの 可視化, 南海卜ラフ巨大地震に備える。愛媛大学防災情報研 究センター, p. $168-180$.

9) Yamagishi, H., Doshida, S. and Pimiento Edgar (2013) : GIS analysis of heavy-rainfall induced shallow landslides in Japan. In Margottini,C. Canuti, P and Sassa, K.(2013) : Landslide Science and Practice, Vol. 1 Landslide Inventory and Susceptibility and Hazard Zoning, p. 601-607. Springer Verlag. （原稿受付2013年 7 月 24 日，原稿受理2013年 8 月23日) 